УДК: 378.147

Самойленко Олександр Миколайович

кандидат педагогічних наук, доцент

Миколаївський національний університет імені В. О. Сухомлинського, м. Миколаїв, Україна

samoylenko65@mail.ru

\title{
СТВОРЕННЯ НОРМАТИВНОЇ БАЗИ НАВЧАЛЬНОГО ПРОЦЕСУ ВНЗ ЯК ЗАСІБ ЗАБЕЗПЕЧЕННЯ ДИСТАНЦІЙНОЇ ФОРМИ НАВЧАННЯ СТУДЕНТІВ
}

\begin{abstract}
Анотація. У статті наведено обгрунтування положень, що становлять нормативну базу забезпечення дистанційної форми навчання бакалаврів-учителів математики в університеті; розкрито функції відділу дистанційної освіти, навчально-методичної лабораторії дистанційного навчання й експертної комісії, сутність інформаційних ресурсів і банку вебресурсів; охарактеризовано кадрове, навчально-методичне та матеріально-технічне забезпечення дистанційного навчання; наведено посадові інструкції системного адміністратора, методиста відділу дистанційної освіти, техніка відділу дистанційної освіти; описано види занять за дистанційною формою навчання й особливості функціонування персональних навчальних веб-ресурсів викладачів.
\end{abstract}

Ключові слова: дистанційна форма навчання; відділ дистанційної освіти; інформаційний ресурс; банк веб-ресурсів; експертна комісія; персональний веб-ресурс.

\section{1. ВСТУП}

Постановка проблеми. 3 розповсюдженням у світі нових інформаційних i технічних засобів доставки навчального матеріалу у вищих навчальних закладах склалися передумови появи і розвитку нового напряму в освіті - дистанційного навчання, яке грунтується на комп'ютерних і телекомунікаційних технологіях. В Україні дистанційне навчання знаходиться на етапі активного становлення, яке визначається умовами економічного розвитку країни і державною політикою в освітній галузі. Основні засади організації i запровадження дистанційного навчання визначаються Положенням про дистанційне навчання [1].

Аналіз основних досліджень. У вітчизняній науково-педагогічній літературі розкриваються питання теорії і методики дистанційного навчання, серед яких можна виділити декілька напрямів здійснених наукових досліджень, а саме: наукове забезпечення дистанційної професійної освіти, проблеми і напрями досліджень в цій галузі (В. Ю. Биков, Н. І. Міхальченко, Л. А. Лещенко та ін.); організаційно-педагогічні основи дистанційної освіти в Україні, підходи до реалізації (В. В. Олійник, В. М. Кухаренко, П. М. Таланчук та ін.).

Мета статті - обгрунтувати нормативну базу дистанційної форми навчання бакалаврів-учителів математики.

\section{2. РЕЗУЛЬТАТИ ДОСЛІДЖЕНЬ}

Для впровадження дистанційної форми навчання в Миколаївському національному університеті імені В.О. Сухомлинського створено нормативну базу супроводження навчального процесу. Нормативна база включала в себе перелік таких документів:

- Положення про дистанційну форму навчання в університеті; 
- Положення про відділ дистанційної освіти;

- Положення про навчально-методичну Лабораторію дистанційного навчання;

- Положення про визнання інформаційних ресурсів;

- Положення про право власності;

- Положення про банк веб-ресурсів;

- Положення про експертну комісію;

- Посадові обов'язки системного адміністратора;

- Посадова інструкція методиста відділу дистанційної освіти;

- Посадова інструкція техніка відділу дистанційної освіти;

- Положення про персональні веб ресурси університету.

Положення про дистанційну форму навчання в університеті регламентує організацію процесу дистанційного навчання. Дистанційне навчання в університеті реалізується через відділ дистанційної освіти, який $є$ структурним підрозділом університету з нормативно-правовою базою, організаційно оформленою структурою, кадровим, системотехнічним, матеріально-технічним та фінансовим забезпеченням, що реалізує дистанційне навчання на рівні вищої освіти.

Положення зазначає, що управління системою дистанційного навчання здійснюється ректором університету і керівником відділу дистанційної освіти. У положенні окреслені стандарти в дистанційному навчанні й організаційні засади системи дистанційного навчання. Взаємовідносини між учасниками навчального процесу за дистанційною формою навчання регулюються відповідними договорами.

Робочий час науково-педагогічних працівників, що забезпечують дистанційне навчання, для виконання навчальних, методичних, наукових, організаційних та інших робіт у поточному навчальному році, не повинен перевищувати річний робочий час, що визначений Кодексом законів України про працю. Враховуючи підвищену складність підготовки методичного і дидактичного забезпечення дистанційних курсів порівняно 3 підготовкою методичних матеріалів для інших форм навчання, керівництву університету дозволяється перерозподіляти робочий час між методичними i навчальними роботами у бік зменшення останніх у порядку, що визначається Міністерством освіти і науки.

Основними видами навчальних занять у дистанційному навчанні в Університеті є: самостійне вивчення студентами навчального матеріалу дистанційного курсу. Самостійне вивчення передбачає використання навчальних матеріалів дистанційних курсів, які студенти одержують через Інтернет i/або на магнітному носії. Вимоги щодо самостійного вивчення навчального матеріалу конкретної дисципліни визначаються навчальною програмою дисципліни, методичними вказівками, інструкціями i завданнями, що містяться у дистанційному курсі. Дистанційне навчання здійснюється на основі таких видів дистанційних занять: лекція, консультація, семінар, дискусія, практичне заняття, лабораторне заняття. Види занять в умовах дистанційної форми навчання дещо відрізняються від занять в умовах очної і заочної форм навчання i визначаються положенням.

Лекція - один із видів навчального заняття у дистанційному навчанні, на якому студенти отримують аудіовізуальну інформацію лекційного матеріалу через засоби телекомунікаційного зв'язку як у синхронному режимі, коли студенти можуть отримувати інформацію від лектора і ставити йому запитання у реальному вимірі часу, так і в асинхронному, коли студенти отримують аудіовізуальний запис лекційного матеріалу.

Консультація - це елемент навчального процесу, за яким студенти дистанційно отримують відповіді від викладача на конкретні запитання або пояснення певних теоретичних положень чи аспектів їх практичного застосування. 
Семінар — це навчальне заняття, що заплановане програмою навчання, під час якого відбувається обговорення вивченої теми, до якого студенти готують тези виступів на підставі виконаних завдань.

Дискусія - це навчальне заняття, проведення якого визначається викладачем у зв'язку з необхідністю розв'язання поточної проблеми, що виникла у студентів у ході навчання, шляхом обговорення її студентами з викладачем і між собою.

Семінар і дискусія проводяться дистанційно в синхронному режимі (у реальному часі) з використанням телекомунікаційної мережі.

Практичне заняття - це навчальне заняття, під час якого відбувається детальний розгляд студентами окремих теоретичних положень навчальної дисципліни і формуються вміння і навички їх практичного застосування шляхом індивідуального виконання ними завдань, що сформульовані в дистанційному курсі. Практичні заняття виконуються дистанційно, результати надсилаються викладачеві електронною поштою.

Лабораторне заняття - форма навчального заняття, яке передбачає, що студенти особисто проводять натурні або імітаційні експерименти чи досліди з метою практичного підтвердження окремих теоретичних положень конкретної навчальної дисципліни, набувають практичних навичок роботи з лабораторним устаткуванням, обладнанням, вимірювальною апаратурою, обчислювальною технікою, методикою експериментальних досліджень у конкретній предметній галузі.

У положенні про відділ дистанційної освіти зазначається, що основна мета відділу дистанційної освіти - надання за дистанційними технологіями освітніх послуг тим, хто навчається без відриву від основної діяльності для отримання вищої освіти, другої вищої освіти, підвищення кваліфікації. Для супроводження роботи в умовах дистанційної форми навчання створено навчально-методичну лабораторію дистанційної освіти. Окреслені напрями роботи лабораторії:

- розробка й апробація засобів навчально-методичного забезпечення дистанційної освіти в університеті;

- дослідження попиту населення щодо дистанційного навчання;

- програмна підтримка дистанційної форми навчання в університеті;

- розробка, створення і супроводження навчальних програм дистанційних курсів;

- забезпечення надійного і безпечного функціонування дистанційних курсів і їх ефективного використання;

- розробка, створення та супроводження сайту відділу дистанційної освіти, забезпечення зручного доступу до нього користувачів дистанційних курсів;

- дослідження у сфері створення, розвитку та функціонування дистанційної освіти;

- розробка технологій виготовлення сучасних електронних засобів навчання;

- проведення навчальних занять з використанням мультимедійних засобів;

- використання Інтернет-ресурсів (електронні бібліотеки, відеотеки, Skypeзв'язок, електронна пошта);

- розробка i виготовлення електронних навчальних видань, методичних рекомендацій із застосування мультимедійних засобів;

- налагодження співробітництва 3 провідними закладами освіти, що використовують дистанційну форму навчання.

Положення про визнання інформаційних ресурсів системи дистанційного навчання також є одним із документів нормативно-правового забезпечення системи дистанційного навчання в університеті. Воно призначене для визнання інформаційних ресурсів системи дистанційного навчання в Університеті і їх окремих елементів як навчально-методичного забезпечення дистанційного навчання, організація і проведення 
якого визначено в Положенні про дистанційне навчання, що затверджено наказом Міністерства освіти і науки України від 21.01.2004 року № 40.

До переліку інформаційних ресурсів системи дистанційного навчання, яким надається статус навчально-методичної праці, відносяться подані нижче.

По-перше: інформаційні ресурси, розміщені на веб-ресурсах системи дистанційного навчання університету і бібліотеки університету. До них можна віднести курси дистанційного навчання, електронні підручники, віртуальні лабораторні роботи і тренажери, ділові ігри.

По-друге: елементи курсу дистанційного навчання. До них відносяться такі структурні одиниці:

- методичні рекомендації для студентів щодо вивчення дисципліни;

- текстова частина змістовного наповнення курсу («лекційний» матеріал);

- глосарій до кожного модулю курсу;

- завдання для практичних робіт з правильними відповідями;

- завдання для контрольних робіт з правильними відповідями;

- тестові завдання (запитання) з правильними відповідями.

По-третє: елементи інших інформаційних ресурсів системи дистанційного навчання:

- науково-методичні розробки у сфері дистанційного навчання;

- педагогічні сценарії навчального процесу за дисципліною 3 використанням технологій дистанційного навчання, електронних підручників;

- сценарії виконання лабораторних робіт 3 використанням віртуальних лабораторій і тренажерів;

- сценарії ділових ігор.

Для визнання інформаційних ресурсів університету або їх окремих елементів навчально-методичною працею необхідно, щоб матеріали, надані автором, відповідали вимогам щодо якості і повноти змістовного наповнення (відповідність навчальному плану, методичне і дидактичне забезпечення, педагогічні й наукові аспекти тощо) i технологічності (структура, наявність необхідних елементів і технологічні можливості конвертування наданих матеріалів у спеціалізоване програмне забезпечення вебресурсу університету. Висновок про якість i повноту змістового наповнення інформаційного ресурсу або його елемента надає відповідна кафедра у вигляді рецензії 3 рекомендацією визнати надані матеріали навчально-методичною працею. Рецензія кафедри надається експертній комісії університету з питань дистанційного навчання.

Положення про право власності й захист авторських прав у галузі дистанційної освіти регулює стосунки між університетом й авторами, які пов'язані з правом власності на результати інтелектуальної діяльності в системі дистанційної освіти і використання інформаційно-комунікаційних технологій у навчальному процесі. Питання прав власності на результати інтелектуальної діяльності у сфері дистанційної освіти в університеті регулюються згідно з чинним законодавством України.

Тимчасове положення про банк веб-ресурсів навчальних дисциплін визначає організаційні, технологічні, навчально-методичні, кадрові і фінансові засади створення і функціонування банку веб-ресурсів навчальних дисциплін у пілотному режимі і діє до виведення банку у штатний режим як складової єдиного інформаційного середовища університету. Головна мета створення і функціонування банку веб-ресурсів навчальних дисциплін - це підвищення якості підготовки, перепідготовки і підвищення кваліфікації фахівців за різними формами навчання (очної, заочної, дистанційної, змішаної) шляхом забезпечення доступу студентам, слухачам, науково-педагогічним i науковим працівникам до якісних веб-ресурсів всіх навчальних дисциплін університету. 
Банк веб-ресурсів навчальних дисциплін університету — це веб-сервіс, який дає змогу авторизованим користувачам університету в єдиному веб-середовищі розробляти, публікувати, зберігати у систематизованому вигляді, шукати i використовувати будь-які веб-ресурси всіх навчальних дисциплін університету. Організація створення і використання банку веб-ресурсів навчальних дисциплін забезпечується відділом дистанційної освіти.

3 метою експертного оцінювання інформаційних блоків створено положення про експертну комісію в галузі дистанційної освіти. Персональний склад експертної комісії призначається навчально-методичною радою університету і затверджується ректором університету. До роботи експертної комісії залучаються фахівці 3 розробки дистанційних курсів і фахівці з предметної галузі дистанційних курсів.

До основних функцій експертної комісії відносяться подані далі.

1. Експертна комісія перевіряє відповідність наданих матеріалів уніфікованим вимогам до дистанційних курсів університету.

2. Експертна комісія перевіряє якість наданих навчальних матеріалів за такими критеріями: повнота (відповідність стандартам навчання, робочим програмам), науковість, доступність, адаптованість для самостійного вивчення, практична направленість.

3. У разі необхідності експертна комісія направляє матеріали на зовнішню рецензію.

4. Експертна комісія розглядає результати експертизи на своїх засіданнях у присутності авторів дистанційних курсів і завідувача кафедри.

5. Результати роботи експертної комісії оформляються у вигляді письмового висновку за результатами експертизи і засідання експертної комісії.

Розроблено окремим документом положення про персональні веб-ресурси науково-педагогічних працівників університету. Персональні веб-ресурси науковопедагогічних працівників університету об'єднанні між собою у віртуальний майданчик. Головною метою функціонування віртуального майданчика персональних веб-ресурсів науково-педагогічних працівників університету $\epsilon$ надання бакалаврам-учителям математики можливості отримати якісні знання, набути уміння й навички відповідно до обраної навчальної програми за місцем їх проживання або тимчасового перебування засобами персональних веб-ресурсів науково-педагогічних працівників університету.

В умовах віртуального майданчика персональних веб-ресурсів науковопедагогічних працівників університету встановлено деякі обмеження. У разі користування віртуальним майданчиком забороняється знищення чи фальсифікація матеріалів, розміщених на віртуальному майданчику персональних веб-ресурсів науково-педагогічних працівників університету; а також зловмисне перевантаження віртуального майданчику персональних веб-ресурсів науково-педагогічних працівників університету на шкоду іншим користувачам.

\section{3. ВИСНОВКИ ТА ПЕРСПЕКТИВИ ПОДАЛЬШИХ ДОСЛІДЖЕНЬ}

Упровадження дистанційної форми навчання у процес підготовки бакалаврівучителів математики має супроводжуватись низкою нормативних документів. До них відносяться нормативні положення, посадові обов' язки та інструкції. Нормативна база має включати в себе перелік таких положень: Положення про дистанційну форму навчання в університеті, Положення про відділ дистанційної освіти, Положення про навчально-методичну Лабораторію дистанційного навчання, Положення про визнання інформаційних ресурсів, Положення про право власності, Положення про банк вебресурсів, Положення про експертну комісію, Положення про персональні веб-ресурси 
університету. Також до нормативної бази відносяться посадові обов'язки й інструкції: Посадові обов'язки системного адміністратора, Посадова інструкція методиста відділу дистанційної освіти, Посадова інструкція техніка відділу дистанційної освіти.

Персональні веб-ресурси педагогічних працівників університету містять в собі упорядковану й систематизовану навчальну інформацію $\mathrm{i}$ надають можливість оптимальної організації навчальної роботи в процесі підготовки бакалаврів-учителів математики. Комунікаційний сектор персонального веб-ресурсу науково-педагогічного працівника університету дозволяє робити проміжний аналіз роботи студентів і надавати їм своєчасну консультацію. Програмні засоби персонального веб-ресурсу науковопедагогічного працівника університету допомагають здійснювати контроль та аналіз роботи студентів в умовах дистанційного навчання. Створені умови персонального вебресурсу науково-педагогічного працівника університету для підготовки бакалаврівучителів математики розширюють можливості доступу студентів зазначених спеціальностей до якісного навчання; забезпечують індивідуалізацію навчального процесу; підвищують якість й ефективність підготовки шляхом застосування дистанційної форми навчання; створюють додаткові можливості для спілкування викладачів із студентами і студентів між собою; забезпечують контроль й аналіз якості підготовки бакалаврів-учителів математики.

\title{
СПИСОК ВИКОРИСТАНИХ ДЖЕРЕЛ
}

1. Наказ Міністерства освіти і науки України (від 25 квітня 2013 р. №466) Про затвердження «Положення про дистанційне навчання» [Електронний ресурс]. — Режим доступу : http://osvita.ua/legislation/Dist_osv/2999/.

Матеріал надійшов до редакиї 12.05.2013 p.

\section{СОЗДАНИЕ НОРМАТИВНОЙ БАЗЫ УЧЕБНОГО ПРОЦЕССА ВУЗОВ КАК СРЕДСТВО ОБЕСПЕЧЕНИЯ ДИСТАНЦИОННОЙ ФОРМЫ ОБУЧЕНИЯ СТУДЕНТОВ}

\author{
Самойленко Александр Николаевич \\ кандидат педагогических наук, доцент \\ Николаевский национальный университет имени В. А. Сухомлинского, г. Николаев, Украина \\ samoylenko65@mail.ru
}

\begin{abstract}
Аннотация. В статье приведено обоснование положений, составляющих нормативную базу обеспечения дистанционной формы обучения бакалавров-учителей математики в университете; раскрыты функции отдела дистанционного образования, учебнометодической лаборатории дистанционного обучения и экспертной комиссии, сущность информационных ресурсов и банка веб-ресурсов; охарактеризованы кадровое, учебнометодическое и материально-техническое обеспечение дистанционного обучения; приведены должностные инструкции системного администратора, методиста отдела дистанционного образования, техника отдела дистанционного образования, описаны виды занятий по дистанционной форме обучения и особенности функционирования персональных учебных веб-ресурсов преподавателей.
\end{abstract}

Ключевые слова: дистанционная форма обучения; отдел дистанционного образования; информационный ресурс; банк веб-ресурсов; экспертная комиссия; персональный вебpecypc. 


\title{
CREATION OF NORMATIVE BASE OF LEARNING PROCESS OF HIGHER EDUCATION ESTABLISHMENTS AS MEANS OF STUDENTS PROVISION BY DISTANCE LEARNING
}

\author{
Olexandr M. Samoilenko \\ $\mathrm{PhD}$ (pedagogical sciences), docent \\ Mykolaiv V. O. Sukhomlynsky National University, Mykolaiv, Ukraine \\ samoylenko65@mail.ru
}

\begin{abstract}
In the article it is presented the rationale of the provisions constituting a regulatory framework providing distance learning undergraduate teachers of mathematics at the university, disclosed the function of distance education, instructional labs and distance learning expert committee, the nature of information resources and the bank's web resources; characterized recruitment, training - methodological and logistical support of distance learning, there are presented job descriptions of system administrator, a trainer of distance education, a technician of distance education department, described the types of classes in the form of distance learning and the peculiarities of personal teachers' educational web resource.
\end{abstract}

Keywords: distance learning; distance education department; resource; Bank of web resources; expert committee; a personal web-site.

\section{REFERENCES (TRANSLATED AND TRANSLITERATED)}

1. Ministry of Education and Science of Ukraine (April 25, 2013 № 466) on the opinion adopted by the "Regulations on Distance Learning" [online]. - Available from : http://osvita.ua/legislation/Dist_osv/2999/ (in Ukrainian). 